\title{
Implementasi Instrumen Kemandirian Belajar Mahasiswa untuk Meningkatkan Prestasi Belajar di Masa Pandemi COVID-19
}

\author{
Wahyudi ${ }^{1}$ Jumadi $^{2}$, Dwi Avita Nurhidayah ${ }^{3}$ \\ 1,2,3 Program Studi Pendidikan Matematika, Fakultas Ilmu Pendidikan, Universitas Muhammadiyah Ponorogo, \\ Jl. Budi Utomo No 10, Ponorogo, Indonesia \\ wahyudi@umpo.ac.id
}

\begin{abstract}
This study improves student learning achievement through independent learning instruments during the covid19 pandemic. This is for reason that has been 2 semesters that the implementation of online mathematics learning must be carried out in the Mathematics Education Study Program, Faculty of Teacher Training and Education, especially for sixth-semester students. The type of research used is classroom action research (CAR) with 2 cycles. Based on the evaluation of learning with fellow educators after carrying out online learning during the covid-19 pandemic, it was concluded that there were one, two, or three groups of ways to solve questions when the learning evaluation was carried out. This means that student learning independence must be considered. On the other hand, students are still dependent and do not have the independence to learn during this online learning. For this reason, this research was conducted to improve student learning achievement through independent learning instruments. It also aims to control how students participate in online math lessons during the COVID-19 pandemic. With this, students need to be accustomed to having independent learning to improve learning achievement in online learning. This study shows that student learning independence can improve student learning achievement. The percentage increase in student learning independence is $12 \%$ and the percentage increase in student learning achievement is $11 \%$.
\end{abstract}

Keywords: Learning Achievement, Instruments, Learning Independence, Learning Mathematics

\begin{abstract}
Abstrak
Penelitian ini melakukan peningkatan prestasi belajar mahasiswa melalui instrumen kemandirian belajar di masa pandemi covid-19. Hal ini beralasan bahwa sudah 2 semester lama pelaksanaan pembelajaran matematika secara daring harus dilakukan di prodi Pendidikan Matematika Fakultas Keguruan dan Ilmu Pendidikan khususnya adalah Mahasiswa semester VI. Jenis penelitian yang digunakan adalah penelitian tindakan kelas (PTK) dengan 2 siklus. Berdasarkan evaluasi pembelajaran bersama rekan-rekan pendidik setelah melaksanakan pembelajaran daring selama pandemi covid-19 ini, disimpulkan bahwa terdapat satu, dua, atau tiga kelompok cara penyelesaian soal saat evaluasi pembelajaran telah dilaksanakan. Artinya bahwa kemandirian belajar mahasiswa harus diperhatikan. Disisi lain mahasiswa masih bergantung dan belum memiliki kemandirian belajar selama pembelajaran daring ini. Untuk itu, penelitian ini dilakukan untuk meningkatkan prestasi belajar mahasiswa melalui instrumen kemandirian belajar. Hal ini juga bertujuan untuk mengontrol bagaimana mahasiswa selama mengikuti pembelajaran matematika yang dilakukan secara daring di masa pandemic covid19 ini. Dengan ini, mahasiswa perlu dibiasakan untuk memiliki kemandirian belajar untuk meningkatkan prestasi belajar di pembelajaran daring. Penelitian ini menunjukkan bahwa kemandirian belajar mahasiswa mampu meningkatkan prestasi belajar mahasiswa. Prosentase peningkatkan kemandirian belajar mahasiswa sebesar $12 \%$ dan prosentase peningkatan prestasi belajar mahasiswa sebesar $11 \%$.
\end{abstract}

Kata kunci: Prestasi Belajar, Instrumen, Kemandirian Belajar, Pembelajaran Matematika

Copyright (c) 2022 Wahyudi, Jumadi, Dwi Avita Nurhidayah

$\triangle$ Corresponding author: Wahyudi

Email Address: wahyudi@ umpo.ac.id (Jl. Budi Utomo No 10, Ponorogo, Indonesia)

Received 18 January 2022, Accepted 17 February 2022, Published 18 February 2022

\section{PENDAHULUAN}

Pandemi covid-19 sampai saat ini masih ada dan semua sektor harus memiliki terobosan dan beberapa alternatif dalam menangani berbagai permasalahan. Salah satu sektor penting yang berkaitan dengan keberlangsungan di masa depan adalah sektor pendidikan. Sudah 2 semester atau satu tahun lamanya di prodi Pendidikan Matematika Fakultas Keguruan dan Ilmu Pendidikan (FKIP) Universitas 
Muhammadiyah Ponorogo yang dulu kegiatan pembelajaran dilaksanakan di kelas, sekarang dilakukan secara daring. Perlu diketahui bahwa mungkin kegiatan pembelajaran daring ini dilakukan pertama kalinya oleh kami (sebagian) yang ada di prodi Pendidikan Matematika FKIP Universitas Muhammadiyah Ponorogo sesuai anjuran dari Pemerintah.

Dengan berlakunya atau dilaksanakannya pembelajaran daring, tentunya ini menjadi suatu tantangkan bagi pendidik di prodi Pendidikan Matematika FKIP Universitas Muhammadiyah Ponorogo untuk lebih intensif dalam mempersiapkan segala hal yang dibutuhkan dalam pembelajaran daring. Mulai dari mempersiapkan perangkat pembelajaran sebagai bahan ajar daring, media pembelajaran daring yang digunakan, penilaian dan evaluasi pembelajaran secara daring dan pelaksanaan pembelajaran daring itu sendiri. Upaya persiapan ini harus dan pasti dilakukan oleh pendidik, agar dalam pelaksanaan pembelajaran daring kualitas dan kuantitasnya sama dengan pelaksanaan pembelajaran seperti biasanya yaitu pelaksanaan pembelajaran luring/tatap muka/di kelas.

Tidak dapat dipungkiri bahwa ini sangat menjadi tantangan bagi pendidik untuk menciptakan suasana pembelajaran daring yang baik dan hasil dari pembelajaran daring juga harus memiliki kualitas yang baik. Namun, walaupun semua perencanaan ini sudah didesain dan diatur dengan baik, apabila tidak terdapat dukungan dan atusias dari mahasiswa, pastinya kegiatan pelaksanaan pembelajaran daring ini tidak akan berjalan dengan baik dan hasil yang diperoleh pasti tidak memuaskan.

Antuasi mahasiswa saat pembelajaran daring sangatlah penting. Pada pelaksanaan pembelajaran luring, mahasiswa dapat berdiskusi materi dengan teman saat pembelajaran, bertukar pikiran dan mampu memberikan kesimpulan serta memutuskan hasil belajar bersama. Terlebih saat pelaksanaan evaluasi pembelajaran luring, mahasiswa melakukan dengan sendiri, percaya diri dan menyelesaikan soal-soal sendiri sesuai kemampuan. Sehingga dengan adanya pembelajaran daring ini, mahasiswa harus memiliki tingkat kemandirian yang lebih. Mahasiswa harus lebih mandiri dalam belajar, lebih intens dalam mengambil keputusan sendiri, memikirkan tujuan belajar dan hasil belajar, serta mahasiswa harus mampu mengevaluasi secara mandiri dengan lebih dan intens. Menurut Hasanah et al ( 2020) pelaksanaan pembelajaran daring menuntut mahasiswa untuk melakukan aktivitas belajar daring secara mandiri. Keterampilan belajar mandiri sendiri merupakan ciri atau karakteristik dalam pembelajaran mandiri. Tahir \& Darwis (2021) menambahkan bahwa ketika pembelajaran daring dapat menimbulkan rangsangan bagi mahasiswa dan mengkaji ulang materi kuliah yang disampaikan oleh dosen, sikap belajar mandiri mahasiswa akan tercipta. Mahasiswa lebih leluasa untuk mengatur waktu belajar pada pembelajaran daring.

Untuk itu kegiatan pembelajaran daring ini juga menjadi tantang bagi Mahasiswa sendiri. Dengan demikian, mahasiswa dalam melaksanakan dan mengikuti pembelajaran daring harus memiki kemandirian belajar. Menurut Sobri et al (2020) dengan adanya pelaksanaan pembelajaran daring ini, mahasiswa harus lebih mandiri belajar dengan kata lain senantiasa tidak tergantung kepada orang lain, 
menetapkan tujuan belajar, mendiagnosis kebutuhan belajar, memiliki rasa percaya diri dan tanggung jawab serta melakukan evaluasi diri. Hal ini juga diperkuat oleh Andiarna \& Kusumawati (2020) yang menyatakan bahwa keterampilan belajar mandiri secara terampil merupakan salah satu hal yang harus dipersiapkan oleh mahasiswa dalam proses pembelajaran daring.

Namun, berdasarkan observasi evaluasi dan pelaksanaan pembelajaran daring selama ini, di beberapa matakuliah seperti matakuliah evaluasi pembelajaran dan matakuliah eksak seperti persamaan diferensial biasa dan fondasi matematika, dari hasil pelaksanaan evaluasi pembelajaran, terdapat satu, dua atau tiga kelompok cara/langkah/model penyelesaian yang dilakukan oleh mahasiswa. Artinya bahwa hasil pekerjaan mahasiswa memikili kemiripan dan kesamaan dengan mahasiswa lainnya. Sehingga dapat diketahui bahwa, kegiatan evaluasi pembelajaran daring ini kemandirian belajar siswa perlu diperhatikan. Hal ini sejalan dengan pendapatnya Hidayat et al (2020) yang menyatakan bahwa kemandirian belajar mahasiswa dalam pelaksanaan pembelajaran daring cenderung lebih rendah. Hal ini disebabkan oleh, mahasiswa karena kebiasan belajar. Andini (2020) menambahkan bahwa rendahnya kemandirian belajar mahasiswa dalam proses pembelajaran daring juga disebabkan salah satunya adalah tidak memanfaatkan waktu luangnya untuk mempelajari kembali materi yang telah didaoat

Berdasarkan paparan di atas, dari evaluasi pembelajaran daring ini, peneliti ingin meningkatkan prestasi belajar mahasiswa dengan instrumen kemandirian belajar di masa pandemi covid-19 ini. Hal ini bertujuan untuk mendukung, mendorong dan mengontrol kemandirian belajar mahasiswa. Apabila ini diperhatikan dengan intens, maka dampak positifnya adalah lulus dari prodi Pendidikan Matematika FKIP Universitas Muhammadiyah Ponorogo memiliki kemandirian yang baik yang dibutuhkan di dunia pekerjaan.

Menurut Rosyid et al (2019) prestasi belajar merupakan hasil yang diperoleh oleh mahasiswa selama pelaksanaan pembelajaran dalam kurun waktu tertentu. Hasil pengukuran dari pelaksanaan pembelajaran ini diwujudkan dalam bentuk angka atau huruf sesuai ketentuan di dalam Universitas. Rosyid et al (2019) menambahkan bahwa terdapat dua faktor yang mempengaruhi dalam prestasi belajar mahasiswa yaitu faktor internal dan faktor eksternal. Faktor internal adalah faktor yang timbul atau berasal dari diri mahasiswa itu sendiri sedangkan faktor eksternal adalah faktor yang datangnya dari luar disi siswa yang dapat dipengaruhi oleh lingkungan keluarga, masyarkat, dan lingkungan alam. Semua faktor ini harus berkontribusi satu sama lain karena mempengaruhi prestasi belajar dan membantu tercapainya prestasi belajar yang baik. Prestasi belajar yang dimaksud disini adalah penguasaan yang dicapai mahasiswa dalam memahami dan mengerti materi matakuliah setelah kegiatan pelaksanaan pembelajaran telah dilakukan.

Menurut Sirait (2016) prestasi belajar merupakan penguasaan pengetahuan dan keterampilan yang dikembangkan dalam materi pembelajaran matematika yang diperoleh melalui proses usaha mahasiswa dalam interaksi aktif subjek dengan lingkungan yang dapat dilihat dari hasil belajar mahasiswa. Menurut Lomu \& Widodo (2018) prestasi belajar merupakan salah satu indikator 
pencapain tujuan nasional pendidikan. Prestasi belajar mahasiswa pada dasarnya dipengaruhi berbagai faktor antara lain faktor dari dalam diri dan juga faktor dari luar diri mahasiswa itu sendiri.

Salah satu faktor utama peningkatan prestasi belajar adalah motivasi dan displin (Lomu \& Widodo, 2018). Mahasiswa yang dengan motivasi dan displin belajar yang tinggi akan selalu bersungguh-sungguh dalam belajar dan dengan tekun mempelajari materi-materi pelajaran yang diperoleh disekolah sehingga kelak mendapat prestasi belajar yang tinggi. Prestasi belajar juga berarti suatu pencapaian yang diperoleh mahasiswa dalam kegiatan belajar. Hal ini diperoleh melalui belajar, mengerjakan tugas, ulangan ataupun ujian pada jenjang pendidikan tertentu dalam bentuk nilai atau angka yang diperoleh dari evaluasi yang dilakukan pendidik. Menurut Ningsih \& Nurrahmah (2016) kecakapan yang dicapai dalam suatu usaha, dalam hal ini usaha belajar dalam perwujudan prestasi belajar yang diliat pada setiap mengikuti tes yang tercermin dari perubahan tingkah laku dan kemampuan belajarnya.

Berdasarkan beberapa uraian mengenai prestasi belajar, maka dapat disimpulkan bahwa prestasi belajar merupakan suatu hasil dari proses belajar yang disimbolkan dengan angka atau huruf yang merupakan perwakilan dari penguasaan materi yang diperoleh mahasiswa selama mengikuti pelaksanaan pembelajaran. Prestasi belajar memiliki hubungan positif dengan kemandirian belajar. Menurut Ningsih \& Nurrahmah (2016) prestasi belajar mahasiswa pada pelaksanaan pembelajaran daring maupun luring dipengaruhi oleh kemandirian belajar. Dengan demikian dapat disimpulkan bahwa apabila mahasiswa memiliki kemandirian belajar tinggi/baik, maka prestasi belajar pun juga akan memperoleh hasil yang baik pula. Apabila kemandirian mahasiswa rendah, pastinya prestasi belajar pun harus diperhatikan dan cenderung rendah juga. Hal ini sesuai dengan pendapatnya Winata et al (2021) yang menyatakan bahwa prestasi belajar mahasiswa dipengaruhi oleh adanya kemandirian belajar mahasiswa. Saefullah et al (2013) menambahkan bahwa kemandirian belajar mahasiswa dan prestasi belajar mahasiswa memiliki hubungan positif (searah) yang signifikan yakni semakin baik sikap kemandirian belajar yang dimiliki mahasiswa, maka akan semakin baik pula prestasi belajar yang diraih mahasiswa.

Menurut Ningsih \& Nurrahmah (2016) kemandirian belajar merupakan kemampuan seseorang dalam mengatur semua aktivitas pribadi, kompetensi, dan kecakapan secara mandiri berbekal kemampuan dasar yang dimiliki individu tersebut, khususnya dalam proses pembelajaran. Menurut Fatihah (2016) kemandirian belajar ditunjukkan dengan adanya kemampuan untuk dapat menyelesaikan masalah yang dihadapi dengan tingkah laku. Dengan adanya perubahan tingkah laku maka mahasiswa memiliki peningkatan dalam berfikir, belajar untuk bisa mandiri tanpa mengandalkan bantuan dari orang lain dan tidak menggantungkan belajar hanya dari pendidik, karena pendidik berperan sebagai fasilitator dan konsultan sehingga pendidik bukanlah satu-satunya sumber ilmu, dan dapat mempergunakan berbagai sumber dan media untuk belajar. Dari beberapa pendapat di atas dapat disimpulkan bahwa kemandirian belajar merupakan kemampuan yang harus dimiliki oleh mahasiswa dalam mengatur semua aktivitas belajar mahasiswa, mulai dari manajemen diri sampai 
mengambil keputusan memikirkan hasil yang akan didapat oleh mahasiswa itu sendiri.

\section{METODE}

Penelitian ini termasuk penelitian Tindakan kelas (PTK). Penelitian PTK ini dilakukan 2 siklus untuk meningkatkan prestasi belajar mahasiswa melalui instrumen kemandirian belajar di masa pandemic covid-19. Subjek penelitian ini adalah mahasiswa semester 6 Prodi Pendidikan Matematika FKIP Universitas Muhammadiyah Ponorogo. Mahasiswa semester 6 Prodi Pendidikan Matematika FKIP Universitas Muhammadiyah Ponorogo dijadikan sebagai subjek penelitian ini dengan alasan bahwa mahasiswa tersebut telah melalui pembelajaran daring selama 2 semester hingga sekarang. Selain itu mahasiswa tersebut juga telah memperoleh beberapa matakuliah eksak dan non-eksak (pendidikan). Dengan demikian, mahasiswa semester 6 ini lebih mendukung sebagai subjek penelitian dalam kegiatan penelitian ini.

Teknik pengumpulan data dilakukan dengan menggunakan lembar observasi dan soal tes. Analisis data dari lembar observasi dilakukan selama kegiatan pembelajaran matematika berlangsung dan analisis dari soal tes dengan cara menghitung prosentase prestasi belajar mahasiswa. Menurut Aqib \& Chotibuddin (2018) PTK merupakan penelitian yang dilakukan pendidik (disini) dengan tekanan pada penyempurnaan atau peningkatan proses dan pratis pembelajaran. Menurut Susilowati (2018) penelitian tindakan merupakan penelitian yang dilakukan melalui tindakan di kelas oleh guru atau peneliti. Penelitian tindakan dapat dikategorikan menjadi empat, yaitu: (1) penelitian tindakan partisipasi (participatory action sesearch), penelitian tindakan kritis (critical action reseach), penelitian tindakan sekolah (institutional action research), dan penelitian tindakan kelas (classroom action recearch). Dalam pendidikan formal, yang banyak dikembangkan guru di sekolah adalah Penelitian Tindakan Kelas (PTK) karena sasaran atau subjek penelitiannya adalah siswa

Indikator kemandirian mahasiswa dalam penelitian ini mengadaptasi maupun memodifikasi dari Hidayati \& Listyani (2010) yaitu: (1) ketidaktergantungan terhadap orang lain, (2) memiliki kepercayaan diri, (3) berperilaku disiplin, (4) memiliki rasa tanggung jawab, (5) berperilaku berdasarkan inisiatif sendiri, dan (6) melakukan kontrol diri. Dalam penelitian ini, nantinya setiap indikator akan dilahirkan beberapa pernyataan yang bersesuaian dengan setiap pernyataan tersebut menggunakan skala likers untuk mengetahui tingkat kemandirian belajar mahasiswa. Skala likers yang digunakan dalam penelitian ini terdiri dari 4 (empat pilihan) yaitu tidak setuju (TS), kurang setuju (KS), setuju (S), dan sangat setuju (SS).

\section{HASIL DAN DISKUSI}

\section{Siklus 1}

Pada siklus 1, pembelajaran matematika dilakukan dua kali pembelajaran dengan alokasi waktu $3 \times 50$ menit. Pertemuan pertama telah dilakukan pada hari Senin tanggal 22 Maret 2021 dan 
pertemuan kedua dilakukan pada hari Senin tanggal 29 Maret 2021. Prosentase kemandirian belajar mahasiswa disajikan dalam Gambar 1 berikut.

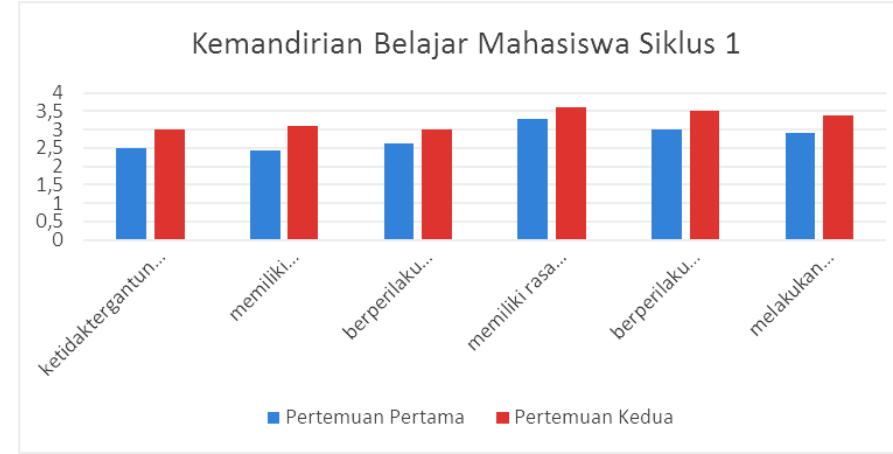

Gambar 1. Kemandirian Belajar Mahasiswa Siklus 1

Dari Gambar 1 di atas diketahui bahwa terdapat perbedaan kemandirian belajar mahasiswa di pertemuan pertama dan pertemuan kedua. Namun perbedaan dari kedua pertemuan tersebut belum begitu nampak. Hal ini disebabkan karena mahasiswa belum membiasakan diri dalam kemandirian belajar. Terlihat bahwa mahasiswa harus lebih memiliki rasa tanggungjawab dalam belajar. Selain itu, mahasiswa masih terbiasa bergantung terhadap orang lain/teman dalam belajar. Mahasiswa juga kurang disiplin dalam belajar dan kurang memiliki inisiatif sendiri dalam menentukan suatu keputusan dalam belajar.

\section{Siklus 2}

Pada siklus 2, pembelajaran matematika dilakukan dua kali pembelajaran dengan alokasi waktu $3 \times 50$ menit. Pertemuan pertama telah dilakukan pada hari Senin tanggal 31 Mei 2021 dan pertemuan kedua dilakukan pada hari Selasa tanggal 08 Juni 2021. Prosentase kemandirian belajar mahasiswa disajikan dalam Gambar 2 berikut.

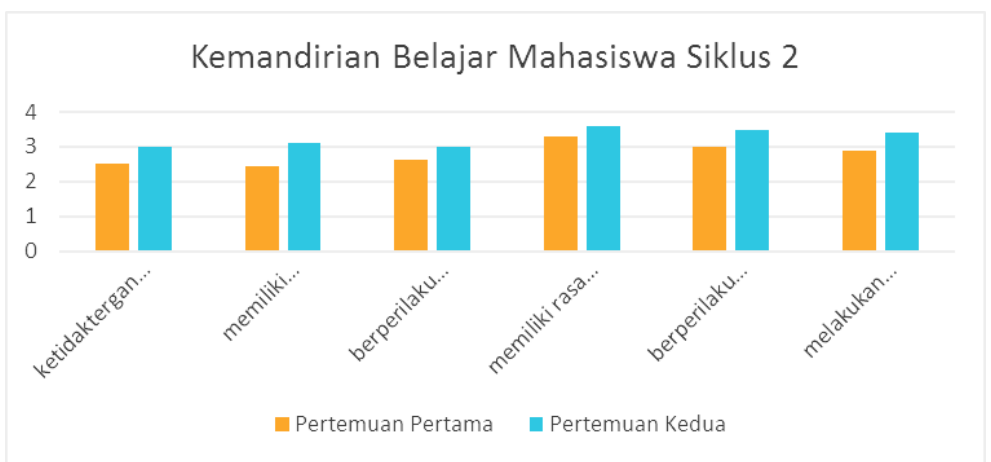

Gambar 2. Kemandirian Belajar Mahasiswa Siklus 2

Dari Gambar 2 di atas terlihat bahwa mahasiswa sudah mulai membiasakan diri sendiri dalam kemandirian belajar. Masing-masing komponen pada kemandirian belajar terdapat perubahan positif. Mahasiswa mampu membuktikan dengan kemandirian belajar dapat menjadikan dampak yang lebih baik. Akhirnya di masa pandemi covid-19 ini, mahasiswa mulai tidak bergantung kepada orang lain dalam belajar. Dengan inisiatif mandiri mahasiswa dan memiliki rasa percaya diri mampu 
menentukan keputusan sendiri dengan bijak. Dalam diri mahasiswa, juga tumbuh rasa tanggungjawab, disiplin, dan mampu mengontrol diri sendiri. Hal ini jelas bahwa dari sklus 1 dan siklus dua kemandirian belajar mahasiswa meningkat sebesar 12\%. Dengan memiliki kemandirian belajar yang baik, mahasiswa akan lebih fokus dalam belajar, sehingga hasil dari belajar tersebut akan meningkat. Berikut Gambar 3 yang menunjukkan hasil belajar siswa dengan kemandirian belajar.

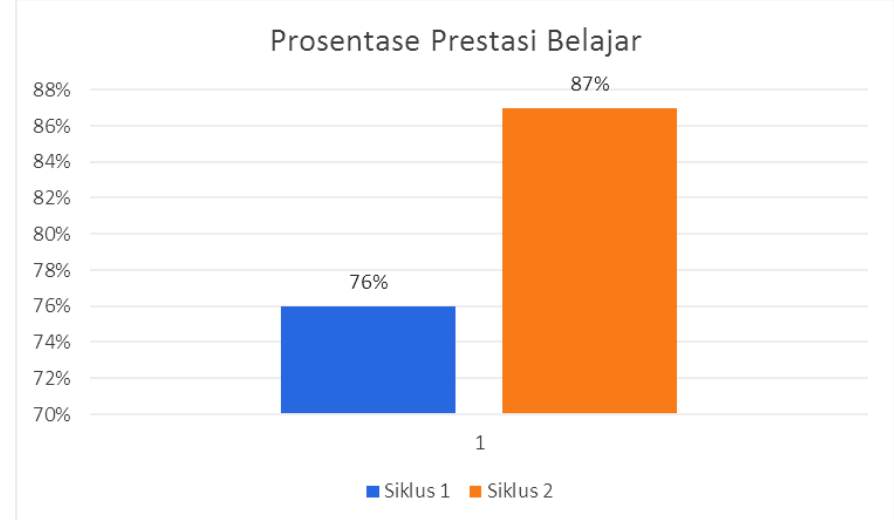

Gambar 3. Prosentase Prestasi Belajar

Dari Gambar 3 di atas dapat diketahui bahwa dengan prestasi belajar menjadi meningkat sebesar $11 \%$. Hal ini karena kemandirian belajar sudah mulai tumbuh pada diri mahasiswa. Dengan demikian, adanya kemandirian belajar mahasiswa harus selalu dipertahankan baik pembelajaran dalam jaringan seperti di pandemi covid-19 ini ataupun di pembelajaran luar jaringan. Hal ini sesuai dengan pendapatnya Laksana \& Hadijah (2019) yang menyatakan bahwa kemandirian belajar mahasiswa mempengaruhi hasil belajar. Meningkatnya hasil belajar mahasiswa dipengaruhi oleh peningkatan kemandirian belajar mahasiswa. Hal ini juga didukung oleh Tahar \& Enceng (2006) yang mengatakan bahwa peningkatan kemandirian belajar mahasiswa berbanding lurus dengan peningkatan hasil belajar mahasiswa.

\section{KESIMPULAN}

Kesimpulan dari kegiatan penelitian ini adalah kemandirian belajar mahasiswa meningkat sebesar $12 \%$ yang berbanding lurus dengan peningkatan prestasi belajar mahasiswa sebesar $11 \%$. Dengan demikian, dapat diketahui bahwa prestasi belajar mahasiswa mampu ditingkatan dengan meningkatkan kemandirian belajar mahasiswa.

\section{REFERENSI}

Andiarna, F., \& Kusumawati, E. (2020). Pengaruh pembelajaran daring terhadap stres akademik mahasiswa selama pandemi Covid-19. Jurnal Psikologi, 16(2), 139-149.

Andini, N. F. (2020). Dampak Pembelajaran Daring Bagi Mahasiswa Masa Pandemi Covid-19. Academia. Edu.

Aqib, Z., \& Chotibuddin, M. (2018). Teori dan Aplikasi Penelitian Tindakan Kelas:(PTK. Deepublish. 
Fatihah, M. A. (2016). Hubungan antara kemandirian belajar dengan prestasi belajar PAI siswa kelas III SDN Panularan Surakarta. At-Tarbawi: Jurnal Kajian Kependidikan Islam, 1(2), 197-108.

Hasanah, A., Lestari, A. S., Rahman, A. Y., \& Daniel, Y. I. (2020). Analisis aktivitas belajar daring mahasiswa pada pandemi Covid-19.

Hidayat, D. R., Rohaya, A., Nadine, F., \& Ramadhan, H. (2020). Kemandirian Belajar Mahasiswa Dalam Pembelajaran Daring Pada Masa Pandemi Covid-19. Perspektif Ilmu Pendidikan, 34(2), $147-154$.

Hidayati, K., \& Listyani, E. (2010). Pengembangan instrumen kemandirian belajar mahasiswa. Jurnal Penelitian Dan Evaluasi Pendidikan, 14(1).

Laksana, A. P., \& Hadijah, H. S. (2019). Kemandirian belajar sebagai determinan hasil belajar siswa. Jurnal Pendidikan Manajemen Perkantoran (JPManper, 4(1), 1-7.

Lomu, L., \& Widodo, S. A. (2018). Pengaruh motivasi belajar dan disiplin belajar terhadap prestasi belajar matematika siswa. In Prosiding Seminar nasional pendidikan matematika etnomatnesia (pp. 745-751).

Ningsih, R., \& Nurrahmah, A. (2016). Pengaruh kemandirian belajar dan perhatian orang tua terhadap prestasi belajar matematika. Formatif: Jurnal Ilmiah Pendidikan MIPA, 6(1).

Rosyid, M. Z., Mansyur, M., IP, S., \& Abdullah, A. R. (2019). Prestasi Belajar. Literasi Nusantara.

Saefullah, A., Siahaan, P., \& Sari, I. M. (2013). Hubungan antara sikap kemandirian belajar dan prestasi belajar siswa kelas X pada pembelajaran fisika berbasis portofolio. WaPFi (Wahana Pendidikan Fisika, 1(1).

Sirait, E. D. (2016). Pengaruh minat belajar terhadap prestasi Belajar Matematika. Formatif: Jurnal Ilmiah Pendidikan MIPA, 6(1).

Sobri, M., Nursaptini, N., \& Novitasari, S. (2020). Mewujudkan kemandirian belajar melalui pembelajaran berbasis daring diperguruan tinggi pada era industri 4.0. Jurnal Pendidikan Glasser, 4(1), 64-71.

Susilowati, D. (2018). Penelitian Tindakan Kelas (PTK) solusi alternatif problematika pembelajaran. Jurnal Ilmiah Edunomika, 2(01).

Tahar, I., \& Enceng, E. (2006). Hubungan kemandirian belajar dan hasil belajar pada pendidikan jarak jauh. Jurnal Pendidikan Terbuka Dan Jarak Jauh, 7(2), 91-101.

Tahir, M., \& Darwis, M. (2021). Belajar Mandiri dan Pembelajaran Berbasis Daring di Perguruan Tinggi. Journal Of Educational Technology, Curriculum, Learning and Communication, 1(1), $28-34$.

Winata, R., Friantini, R. N., \& Astuti, R. (2021). Kemandirian belajar dan kedisipilinan belajar terhadap prestasi mahasiswa pada perkuliahan daring. JURNAL E-DuMath, 7(1), 18-26. 